\title{
Book Review Index
}

\section{Names in brackets are those of the reviewers}

Bresch, C. and Hausmann, R.: Klassische und molekulare Genetik, 2nd Ed. (P. E. Polani): 73

Chiarelli, A. B., ed.: Comparative genetics in monkeys, apes and man (J. Buettner-

Janusch): 454 Cohn, N. S. Elements of cytology, 2nd Ed. (K.W. Jeon): 65 Cortynas de Nava, M. C: Les anomalies chromosomiques au cours des hémopathies malignes et non malignes. Une etude de 171 cas. Monographies des Annales de Géné-

tique (Mary Martineau) : 71 Cowie, V. A.: A study of the early development of mongols (H. F. R. Prechtl) : 70

Dertinger, H. and Juno, H.: Molekulare Strahlenbiologie (J. W. Boag)!: 70

Ford, C. E. and Harris, H., eds.: New aspects of human genetics (J. A. Fraser-Roberts)):

228 Fuchs, G.: Mathematik für Mediziner und Biologen (C. A. B. Smith): 70

Genetic concepts and neoplasia. A collection of papers presented at the twenty-third Annual Symposium on Fundamental Cancer Research, 1969 (N. B. Atkin,)!: 72

John, B. and Lewis, K. R.: The chromosome cycle. Kern- und Zellteilung B. Protoplasma-

tologia, Band VI (P. Barlow): 68 Jonsson, G.: Quantitation of fluorescence of biogenic amines. Demonstrated with the

formaldehyde method. Progress in Histochemistry and Cytochemistry, Vol. 2, No. 4

(R. G. Spector): 452

Kallos, P. and Waksman, B. H., eds.: Progress in allergy, Vol. 14 (M. Adynolfi): 75 Komma, K., ed.: Mathematical topics in population genetics. Biomathematics, Vol. 1 (C. A. B. Smith): 229

Levitan, M. and Montagu, A.: Textbook of human genetics (J. Insley): 452

Nielsen, J.: Klinefelter's syndrome and the XYY syndrome: a genetical, endocrmological and psychiatric-psychological study of thirty-three severely hypogonadal male patients and two patients with karyotype 47,XYY. Acta psychiat. scand., Suppl. 209 (J. Money) : 67

Nielsen, J.; Sørensen, A.; Thellgaard, A.; Frøland, A. and Johnsen, S. G.: A psychiatric-psychological study of 50 severely hypogonadal male patients, including 34 with Klinefelter’s syndrome, 47 ,XXY (J. Money): 66

Ohno, S.: Evolution by gene duplication (J. R. S. Whittle): 77 Oxford Biology Readers (P. E. Polani): 454

Book Review Index 
Reinert, J. and Ursprung, H., eds.: Origin and continuity of cell organelles (D. Wilkie) :

228 Rondanelli, E. G.; Gorini, P.; Gerna, G. and Magliulo, E.: Pathology of erythroblastic

mitosis in occupational benzenic erythropathy and erythremia. Bibliotheca Haemato-

logica, No. 35 (D. G. Harnden): 63 Rose, A. and Harrison, J. S., eds.: The biology of yeasts. The Yeasts, Vol. 1 (D. Wilkie) :

Sachs, E. S.: Trisomy G/normal mosaicism. A cytologicaland clinical investigation (Angela

I.Taylor): 452 Stebbins, G. L.: Chromosomal evolution in higher plants (S. R. J. Woodell) : 74

W $\pi$ tmann, H. G. and Schuster, H., eds.: Molecular genetics (D. C. Watts): 76 